Published in final edited form as:

Curr Opin Organ Transplant. 2013 April ; 18(2): 179-185. doi:10.1097/MOT.0b013e32835f0887.

\title{
New and old technologies for organ replacement
}

\author{
Jeffrey L. Platt ${ }^{a, b}$ and Marilia Cascalho ${ }^{a, b}$ \\ aDepartment of Surgery, University of Michigan, Ann Arbor, Michigan, USA \\ bDepartment of Microbiology and Immunology, University of Michigan, Ann Arbor, Michigan, USA
}

\begin{abstract}
Purpose of review-The demand for organ transplantation has increased over time, increasingly exceeding the supply of organs. Whether and how new or old technologies separately or together could be applied to replacing organs will thus remain a question of importance.

Recent findings-Estimating how the demand for organ transplantation will evolve over the decades and the need to bring forward and test new technologies will help establish the dimensions of the problem and the priorities for investigation. Pluripotent stem cells can in principle expand to sufficient numbers, differentiate, and assemble complex and functional organs. However, the devising of effective and reliable means to coax the stem cells to do so remains beyond the current grasp.
\end{abstract}

Summary-Given the time during which novel therapies are devised and applied, which organ transplantation reaches to 2-3 decades, one can anticipate the need for organ replacement will grow dramatically, but advances in science and technology will overcome the hurdles in generating new organs. Whether these advances will address the needs and priorities of society, however, is unclear.

\section{Keywords}

embryonic stem cells; organ allocation; organogenesis; pluripotent stem cells; xenotransplantation

\section{INTRODUCTION}

About a decade ago, we considered, largely on theoretical grounds, how new and old technologies such as cloning, genetic engineering, tissue engineering, and cellular transplantation might be used to replace or improve the function of failing organs [1-4]. The severe shortage of human organs for transplantation, which slows the delivery of optimum therapy for some and prevents the delivery of optimum therapy for many more patients, motivated these considerations. With the passage of time and advances in medical care and technology, this shortage has become even worse and hence it would seem at least as

Correspondence to Jeffrey L. Platt, MD, University of Michigan, Biomedical Sciences Research Building, 109 Zina Pitcher Place, Ann Arbor, MI 48109, USA. Tel: +1 734615 7755; plattj1@umich.edu.

Conflicts of interest

The authors have no conflicts of interest for this communication. 
appropriate now as in the past to consider the dimensions of the problem and solutions with the potential to address to it.

\section{ANTICIPATING FUTURE DEMAND FOR ORGAN REPLACEMENT}

The most thorough evaluation of demand for organ transplants and supply of organs for transplantation were published by Evans [5] 10 years ago. Although such thorough analysis has not been updated, one has the sense that the general conclusions reached then seem applicable today. As Table 1 shows, the aggregate demand for organ transplantation, as measured by the number of patients on waiting lists for transplantation, has certainly increased in the last decade (Table 1). But, this table considers only those individuals actually 'listed' for transplants and does not include those who might be listed but are not because providers have not considered transplantation as an a therapeutic option or have considered availability of organs too remote. Further, the aggregate increase in demand obscures more dramatic increases in the demand for some organs and decreases in demand for others. Thus, as Fig. 1, taken from the Annual Report of Organ Procurement and Transplantation Network (OPTN) and Scientific Registry of Transplant Recipients (SRTR) [6--], shows the demand for kidney transplants has nearly doubled in the last decade, whereas the demand for lung transplants has nearly halved. At the same time, as Fig. 1 shows, the number of organs available hence for the most part the number of transplants has not changed (except the availability of living donors) and the use of marginal donors has allowed more kidney transplant to be performed [7]. But, this approach neglects the changes in overall population. Adjustment for the $10 \%$ increase in the population of the USA in the last decade has had little impact on the demand but reveals that the number of transplants, adjusted for population, has decreased, except for kidney.

Adjustment for population does not impact on the estimates of the current demand for transplantation and might not have served the analysis of prior demand because such adjustments are eclipsed by the improvements in medical and surgical practice that caused transplantation to evolve from a high-risk experiment to a routine procedure. On the other hand, we believe changes in population, demographics, and epidemiology of disease are central to any consideration of how technologies, the development, testing, approval, and routine application of which can span decades (as in the case of organ transplantation) will meet the needs of society. Indeed, some of our early considerations of this subject were remiss in considering only the existing supply and demand [8].

The PEW Research Center has published projections, which, if not particularly surprising, do help one imagine how demand might change over the next 20-30 years [9]. Not only is the population expected to expand during the next 3 decades, but also the demographic profile of the USA will change dramatically [9]. One important change will be in the numbers: the 'elderly', defined as those over age 65. In 2030, the elderly will comprise nearly $20 \%$ of the population, which will have swelled by nearly 100 million, versus about $12 \%$ today. If the next decades bring no other changes, the demand for organ transplantation, which we assume to be cumulative with age, will certainly increase. And, because the incidence and prevalence of heart failure and renal failure increase with age, the demand should increase still more. 
Yet another demographic factor could change the demand of transplantation and the supply of organs profoundly. Immigration will account for most if not all of the growth of the population of the USA during the next 30 years [9]. Most immigrants will be Hispanic, some Asian. Immigration could well impact on the types of diseases people experience, the demand for organ transplants, and the frequency of organ donation. Changes in immigration law and extension of health benefits should also increase the demand.

On the other hand, one might hope that advances in medicine and surgery that bring new cures and improvements in care for diseases might in turn decrease the demand for organ transplants. Yet, experience in Europe and the USA suggests otherwise. Thus, greater appreciation of the importance of controlling hypertension and hypercholesterolemia, and the availability of new drugs and devices have dramatically decreased the morbidity and mortality of cardiovascular disease in Europe and the USA [10], yet the number of patients listed for heart transplants has increased [11-्]. Nor will changes in the epidemiology of disease likely decrease the demand. As mortality of cardiac disease in the USA decreased from approximately 300 per 100000 population to approximately 150 per 100000 , the prevalence of diabetes and hypertension increased [12].

Discoveries and advances in molecular diagnosis, genomics, personalized medicine, etc., might increase still further the demand for organ transplantation. Transplantation of the kidney [13], liver [14,15], and pancreas [16] are occasionally performed in patients considered to be at high risk of developing lethal disease such as cancer. Although these procedures are rare today, the demand will only expand as the basic and clinical knowledge increases [17].

\section{NEW AND OLD TECHNOLOGIES FOR REPLACING ORGAN FUNCTION}

We previously considered how new and existing technologies might be applied separately and together toward the replacing of organ function $[1,4,18]$. Some of these technologies are listed in Table 2 and an example of how the technologies might be combined is illustrated in Fig. 2. Ten years ago, one might thoroughly review and critically discuss this subject in a communication such as this one; however, expansion of knowledge and technique makes that all but impossible today. Instead, we shall offer our perspective on a few key advances and unanswered questions.

One subject that has resonated with the scientists, physicians, and the public has been the potential use of stemcells to treat disease, including organ failure [19]. Some applications of stem cells have focused on repairing damaged organs such as the heart [20-m]. Others have focused on generating new tissues and organs. We shall consider only the later, and for the most part strategies in which stem cells are coaxed to differentiate into functioning tissue or an organ that can be transplanted into a patient.

Because tissues and organs contain numerous types of cells in more or less complex anatomic arrays, efforts to generate new tissues and organs usually involve the use of stem cells which can proliferate for many generations, perhaps indefinitely and differentiate into many different types of mature cells, that is, pluripotent stem cells $[19,21]$. Pluripotent stem 
cells were first isolated from the murine teratomas and after injection into the murine blastocysts were found to contribute to the formation of all tissues in the mosaic offspring $[22,23]$. The archetype of pluripotent stem cells is the embryonic stem cell [24]. Because embryonic stems are inevitably histoincompatible with those who would need treatment, effective use of these cells and especially of their differentiated progeny seemed to depend on the selection of least incompatible cells from a 'library' or engineering of histocompatibility [21]. Still, no matter how large a library of embryonic cells might be and despite the intensive efforts to engineer cells to make them less histoincompatible, one can no more assume embryonic stem cells can be selected or made histocompatible than one can assume bone marrow stem cells or donated organs can be selected or made histocompatible. Hence, the use of these cells for life-sustaining functions would probably require immunosuppression. Use of embryonic stem cells and their progeny is also hindered by the ethical concerns and by the observation in nearly every experimental system that after the transfer into histocompatible and even some histoincompatible individuals, the cells would generate teratomas and teratocarcinomas [25].

Transfer of nuclei into a zygote or blastocyst cell to bring about nuclear reprogramming can achieve better histocompatibility. Nuclear transfer can generate stem cells that are manifestly pluripotent and capable of generating intact animals, and capable of contributing to the germline [26]. Commonly referred to as 'reproductive cloning' when newly fashioned cells are used to generate whole animals and 'therapeutic cloning' when cells, tissues, or organs are to be produced $[1,4,27]$, nuclear transfer could in principle be used to generate histocompatible cells for efforts to repair or replace failing organs. However, the progeny of stem cells generated by the nuclear transfer are not fully histocompatible with the source of the nucleus because the stem cells has the mitochondrial genome of the reprogramming cell, which encodes some minor histocompatibility antigens and the cells like embryonic stem cells, which generate teratomas [28]. And, if the 'reprogramming cell' derives from a human embryo, this approach provokes the same ethical concerns as the use of embryonic stem cells. Some efforts have been made to use xenogeneic embryonic cells to reprogram mature cells, but the full promise of this approach is not yet clear.

Fortunately, the recent years have brought dramatic advances in the understanding and practice of nuclear reprogramming and with it those increasing hope that stem cells might be used to repair or replace failing organs. Nuclear reprogramming can now be accomplished by the expression of a definable set of genes in mature cells [29,30], yielding 'induced pluripotent stem cells' or 'iPS cells'. Expression of these genes is usually accomplished by the transfer of viral transforming genes $[30,31 \cdot \mathbf{m}, 32 \mathbf{m}]$; however, fusion of donated oocytes with somatic cells [33], exposure to extracts from primitive cells [34], and defined substances might soon replace the need for gene transfer [35m].

Generation of pluripotent stem cells with such 'cloning factors' [18], a term we use to denote averting of gene transfer, is especially pertinent to tissue and organ replacement because with the exception of the fusion approach, the genome of the reprogrammed cells, both nuclear and mitochondrial, would derive fully from the donor of the mature cell, that is, the person to be treated. Hence, the stem cell should have no foreign genes. Further, generation of pluripotent stem cells in this way does not require use or destruction of a 
human embryo and hence avoids the most vexing ethical concerns. Still, induced pluripotent stem cells can form tumors [36] and hence, with full or near histocompatibility, this barrier remains.

Our commentary, to this point, has assumed that pluripotent stem cells containing no foreign DNA would be fully histocompatible with the individual from whom the DNA was obtained. However, some recent work has challenged this concept. Teratomas generated by the inoculation of induced pluripotent stem cells into the mice of the same strain were found to be immunogenic and indeed to be rejected in contrast to the teratomas formed from the embryonic stem cells [37-m]. Needless to say, this observation seemed to indicate that induced pluripotent stem cells might not be immunologically superior to embryonic stem cells. However, this unexpected 'alloimmune' phenomenon has not been observed by all investigators and indeed it might be peculiar to the experimental system used [35m,38m]. From our perspective, we think the apparent immunogenicity of the induced pluripotent stem cells can be explained by the technical factors and that the key questions will not be immunogenicity, as immunosuppression, if needed, is obviously acceptable to allow organ replacement. Rather, the key questions to us are whether pluripotent stem cells will generate tumors, whether applications using those cells can be made efficient enough to impact on the problem of organ failure, and whether the cells will be able to generate organ replacements. We will consider this third question in the section that follows.

\section{CAN PLURIPOTENT STEM CELLS REPAIR OR REPLACE FAILING ORGANS?}

From our perspective, the most daunting challenge key for those who would use stem cells to replace the function of failing organs is whether and how those cells can be parlayed into an organ or organ-like structure of sufficient mass and aggregate function to actually serve the afflicted patient. As teratoma cells [22], embryonic stem cells [39], stem cells cloned by nuclear transfer [26,40], and induced pluripotent stem cells [30,39] can generate whole animals with full-sized, functioning organs, this challenge should be surmountable. Pluripotent stem cells, originated from fibroblasts, have been used to generate enough insulin-secreting cells with sufficient function to reverse hyperglycemia in mice with type 2 [41] and type 1 [42] diabetes. Generation of hepatocyte-like cells from human-induced pluripotent stem cells has been reported [43], but whether cells such as these can be made fully mature and functional has been questioned [44]. As pluripotent stem cells of various types can generate whole animals, we think the means will be found to use them to generate mature and functional cells.

The larger question, in our view, is how to generate an implantable structure that can replace the function of an organ. Even if the replacement of the beta cells of a pancreas can be envisioned and generation of mature hepatocytes to supplement hepatic function is at hand, a whole intact heart, kidney, or lung is not produced. Of course, the heart, and perhaps someday the lung, might be replaced by a device. But, implantation of a living organ or organ-like structure, even if it is not fully compatible with host, will be preferred in some 
circumstances and hence the question is whether and how generation of an intact, complex organ can be accomplished.

Four approaches for the generation of organ replacements will be discussed briefly here.

First, mature tissue and even intact rodent organs have been generated in vitro by exploiting the natural ability of undifferentiated but committed fetal cells to form relatively differentiated and complex structures [45]. Organogenesis in vitro can yield fully differentiated cells [46]; however, tissues so generated lack blood vessels and do not approach the size of fetal organs [47], and achieving the size needed to replace an organ in a mature human would seem beyond the current or anticipated capabilities.

Second, artificial devices and implantable organs have been proposed, and some constructed by seeding matrices, including de-cellularized organs, with mature cells or their precursors $[48,49-\mathbf{m}$. Perhaps, the most advanced of these are the 'bio-artificial liver devices', which in experimental systems and clinical trials can exhibit discernable levels of function and clinical benefit [50]; however, the devices have not been advanced to the point where they could be applied for the long-term treatment of hepatic failure [51,52]. Nor have autologous stem cells been used toward this end [53]. Thus, from a current perspective, an implantable, long-term liver replacement stands beyond the current technologies. Efforts are being made to use de-cellularized hearts and kidneys as a substrate for generating implantable cardiac and renal replacements $[48,49-\mathbf{m}$. Seeding de-cellularized rodent heart with cardiac muscle cells and endothelial cells has yielded exciting levels of function in vitro [54], but long-term in-vivo testing and especially the development and testing of hearts repopulated using stem cells or their derivatives have not been reported and would seem remote, at least today.

Third, undifferentiated fetal cells or partly differentiated stem cells or their derivatives might be implanted into the person to be treated, allowing in-vivo organogenesis to occur $[55,56]$. Primitive cells from the animal fetuses have been advanced with some success; however, use of pluripotent stem cells in lieu of fetal cells has not been tested.

Fourth, stem cells, of various types, might be engrafted into a developing xenogeneic fetus, allowing the microenvironment and growth factors of the fetus to coax the development of mature cells or of an organ, which can be transplanted into the person to be treated $[1,4,18]$. Human hematopoietic stem cells engrafted in fetal swine generated a functional human immune system in the offspring [57] and some mature human nephrons in the swine kidneys [58]. However, whether this approach could be used to generate primordia in turn capable of generating whole human organs has not been tested and we fear the hurdles to doing so are considerable.

In sum, although many now envision the use of stem cells to generate organs or replace organ functions, no particular approach has emerged to accomplish that end. Still, even if one or several of these approaches prove biologically unfeasible, others mentioned above or yet to be discovered will surely succeed. Rather, the limitation to replacing organ function may eventually reside in the barriers beyond technology. 


\section{CONCLUSION}

The demand for organ transplantation today far exceeds the supply of human organs. We estimate that this demand, over the next 2-3 decades, which the history of organ transplantation suggests to be the time needed to establish novel technologies, will grow dramatically. And, even with the advances in medicine and public policies, we doubt the supply of human organs will ever keep pace with the demand and hence there will remain an urgency of finding other approaches and this urgency will increase with time. Organs generated in one way or another using the stem cells derived from the individual to be treated seem the most obvious, if not entirely ripe, solution to this problem. Despite the hurdles presently recognized and some yet to be discovered, we have every confidence that safe and reliable means to generate functional human organs or organ replacements will be found. However, we wonder whether society, at least in the USA, will be willing and able to absorb what we think will be a very high cost of generating stem cells for each individual needing treatment, coaxing the stem cells to form organs, and implanting the organs in the vast numbers of an aging population with organ failure, cancer, or other lethal conditions. Generating and testing personalized pluripotent stem cells, expanding the cells to the mass of a kidney or liver, and implanting the personalized organ will be vastly more expensive than allogeneic organ transplantation, even allowing that ongoing immunosuppression may not be needed. We suspect this problem might lead the transplant community either to regain enthusiasm for xenotransplantation or to finally grapple with the ethical challenges of rationing healthcare.

\section{Acknowledgments}

None.

Work in the authors' laboratories has been supported by the National Institutes of Health.

\section{REFERENCES AND RECOMMENDED READING}

Papers of particular interest, published within the annual period of review, have been highlighted as:

- of special interest

-m of outstanding interest

Additional references related to this topic can also be found in the Current World Literature section in this issue (pp. 243-244).

1. Cascalho M, Platt JL. Xenotransplantation and other means of organ replacement. Nat Rev Immunol. 2001; 1:154-160. [PubMed: 11905823]

2. Ogle BM, Platt JL. Approaches to the replacement of the function of failing organs. Curr Opin Organ Transplant. 2002; 7:28-34.

3. Cascalho M, Ogle BM, Platt JL. Xenotransplantation and the future of renal replacement. J Am Soc Nephrol. 2004; 15:1106-1112. [PubMed: 15100350]

4. Ogle BM, Cascalho M, Platt JL. Fusion of approaches to the treatment of organ failure. Am J Transplant. 2004; 4(Suppl. 6):74-77. [PubMed: 14871276]

5. Evans, RW. Coming to terms with reality: why xenotransplantation is a necessity. In: Platt, JL., editor. Xenotransplantation. Washington, D.C: ASM Press; 2001. p. 29-51. 
6. Organ Procurement and Transplantation Network (OPTN) and Scientific Registry of Transplant Recipients (SRTR). OPTN /SRTR 2010 Annual Data Report. 2011Rockville, MDDepartment of Health and Human Services, Health Resources and Services Administration, Healthcare Systems Bureau, Division of Transplantation The authoritative source of information on the demand for organ transplants and number of transplants performed in the USA. Although providing the most accurate current picture and one that parallels Europe, it has limited ability to project the future needs.

7. Wynn JJ, Alexander CE. Increasing organ donation and transplantation: the U.S. experience over the past decade. Transpl Int. 2011; 24:324-332. [PubMed: 21208297]

8. Platt JL, Vercellotti GM, Dalmasso AP, et al. Transplantation of discordant xenografts: a review of progress. Immunol Today. 1990; 11:450-456. [PubMed: 2073317]

9. Passel, JS.; Cohn, D. Pew Research Center Social and Demographic Trends. Washington, D.C: 2008. U.S. population projections: 2005-2050.

10. Laribi S, Aouba A, Nikolaou M, et al. Trends in death attributed to heart failure over the past two decades in Europe. Eur J Heart Fail. 2012; 14:234-239. [PubMed: 22237388]

11. Starling RC. Advanced heart failure: transplantation, LVADs, and beyond. Cleve Clin J Med. 2013; 80:33-40. [PubMed: 23288942] A clear and salient portrait of approaches to the treatment of cardiac failure, including transplantation, devices, and medical therapies. This study suggests that advances in the treatment of organ failure do not necessarily decrease the demand for transplantation.

12. Balamurugan A, Mehta P, Bates J, Mehta JL. Change in mortality from coronary heart disease and stroke in Arkansas (1979 to 2007). Am J Cardiol. 2011; 107:156-160. [PubMed: 21211595]

13. Marega A, Fregonese C, Tulissi P, et al. Preemptive liver-kidney transplantation in von Gierke disease: a case report. Transplant Proc. 2011; 43:1196-1197. [PubMed: 21620087]

14. Schwartz M, Roayaie S, Konstadoulakis M. Strategies for the management of hepatocellular carcinoma. Nat Clin Pract Oncol. 2007; 4:424-432. [PubMed: 17597707]

15. Fouzas I, Sotiropoulos GC, Molmenti EP, et al. 'Preemptive' live donor liver transplantation for fibrolamellar hepatocellular carcinoma: a case report. Transplant Proc. 2008; 40:3806-3807. [PubMed: 19100497]

16. Sharma RR, London MJ, Magenta LL, et al. Preemptive surgery for premalignant foregut lesions. J Gastrointest Surg. 2009; 13:1874-1887. [PubMed: 19513795]

17. Cascalho, M.; Platt, JL. Emerging strategies in kidney transplantation: a companion to Brenner and Rector's the kidney. In: Himmelfarb, J.; Sayegh, MH., editors. Chronic kidney disease, dialysis, and transplantation. 3rd. Philadelphia: Saunders; 2010. p. 628-635.

18. Cascalho M, Platt J. New technologies for organ replacement and augmentation. Mayo Clin Proc. 2005; 80:370-378. [PubMed: 15757019]

19. National Research Council (U.S.). Committee on the Biological and Biomedical Applications of Stem Cell Research, Institute of Medicine (U.S.). Board on Neuroscience and Behavioral Health. Stem cells and the future of regenerative medicine. Washington, D.C: National Academy Press; 2002.

20. Anversa P, Kajstura J, Rota M, Leri A. Regenerating new heart with stem cells. J Clin Invest. 2013; 123:62-70. [PubMed: 23281411] This study puts forward the idea that de-cellularized organ might be used as a scaffold for generating a new organ.

21. National Research Council (U.S.). Committee on Guidelines for Human Embryonic Stem Cell Research, National Research Council (U.S.), Board on Health Sciences Policy, Institute of Medicine (U.S.). Guidelines for human embryonic stem cell research. Washington, D.C: National Academies Press; 2005.

22. Illmensee K, Mintz B. Totipotency and normal differentiation of single teratocarcinoma cells cloned by injection into blastocysts. Proc Natl Acad Sci USA. 1976; 73:549-553. [PubMed: 1061157]

23. Martin GR. Teratocarcinomas and mammalian embryogenesis. Science. 1980; 209:768-776. [PubMed: 6250214]

24. Thomson JA, Itskovitz-Eldor J, Shapiro SS, et al. Embryonic stem cell lines derived from human blastocysts. Science. 1998; 282:1145-1147. [PubMed: 9804556] 
25. Koch CA, Platt JL. Immunosuppression by embryonic stem cells. Stem Cells. 2008; 26:89-98. [PubMed: 17962705]

26. Campbell KH, McWhir J, Ritchie WA, Wilmut I. Sheep cloned by nuclear transfer from a cultured cell line. Nature. 1996; 380:64-66. [PubMed: 8598906]

27. Cascalho, M.; Ogle, BM.; Platt, JL. Organogenesis and cloning. In: Gruessner, R.; Benedetti, E., editors. Living donor organ transplantation. New York: McGraw-Hill; 2008. p. 769-772.

28. Imberti B, Casiraghi F, Cugini D, et al. Embryonic stem cells, derived either after in vitro fertilization or nuclear transfer, prolong survival of semiallogeneic heart transplants. J Immunol. 2011; 186:4164-4174. [PubMed: 21389254]

29. Takahashi K, Yamanaka S. Induction of pluripotent stem cells from mouse embryonic and adult fibroblast cultures by defined factors. Cell. 2006; 126:663-676. [PubMed: 16904174]

30. Okita K, Ichisaka T, Yamanaka S. Generation of germline-competent induced pluripotent stem cells. Nature. 2007; 448:313-317. [PubMed: 17554338]

31. Kim J, Lengner CJ, Kirak O, et al. Reprogramming of postnatal neurons into induced pluripotent stem cells by defined factors. Stem Cells. 2011; 29:992-1000. [PubMed: 21563275] One of the several recent reports on conversion of mature, nonproliferating cells into pluripotent stem cells. An approach such as this one might be used to produce stem cells which in turn might be coaxed to form an organ.

32. Robinton DA, Daley GQ. The promise of induced pluripotent stem cells in research and therapy. Nature. 2012; 481:295-305. [PubMed: 22258608] This study provides a thorough and current review of how pluripotent stem cells are generated, how they might be used, and limitations and obstacles to use.

33. Noggle S, Fung HL, Gore A, et al. Human oocytes reprogram somatic cells to a pluripotent state. Nature. 2011; 478:70-75. [PubMed: 21979046]

34. Hansis C, Barreto G, Maltry N, Niehrs C. Nuclear reprogramming of human somatic cells by xenopus egg extract requires BRG1. Curr Biol. 2004; 14:1475-1480. [PubMed: 15324664]

35. Blanpain C, Daley GQ, Hochedlinger K, et al. Stem cells assessed. Nat Rev Mol Cell Biol. 2012; 13:471-476. [PubMed: 22678486] This study provides brief but salient comments by six authorities on pluripotent stem cells, particularly induced pluripotent stem cells.

36. Griscelli F, Feraud O, Oudrhiri N, et al. Malignant germ cell-like tumors, expressing Ki-1 antigen (CD30), are revealed during in vivo differentiation of partially reprogrammed human-induced pluripotent stem cells. Am J Pathol. 2012; 180:2084-2096. [PubMed: 22425713]

37. Zhao T, Zhang ZN, Rong Z, Xu Y. Immunogenicity of induced pluripotent stem cells. Nature. 2011; 474:212-215. [PubMed: 21572395] This study reported the arresting observation that induced pluripotent stem cells and their progeny might provoke immunity (autoimmunity?) and destruction of tissue formed by the cells. Whether this finding applies only to the particular system used or would be observed more broadly is a subject of heated debate.

38. Barrilleaux B, Knoepfler PS. Inducing iPSCs to escape the dish. Cell Stem Cell. 2011; 9:103-111. [PubMed: 21816362] This study thoroughly and saliently reviews the key questions that must be addressed if pluripotent stem cells or their progeny are to be brought to clinical application.

39. Carstea AC, Pirity MK, Dinnyes A. Germline competence of mouse ES and iPS cell lines: chimera technologies and genetic background. World J Stem Cells. 2009; 1:22-29. [PubMed: 21607104]

40. Lai L, Kolber-Simonds D, Park KW, et al. Production of a-1,3-galactosyltransferase knockout pigs by nuclear transfer cloning. Science. 2002; 295:1089-1092. [PubMed: 11778012]

41. Alipio Z, Liao W, Roemer EJ, et al. Reversal of hyperglycemia in diabetic mouse models using induced-pluripotent stem (iPS)-derived pancreatic beta-like cells. Proc Natl Acad Sci USA. 2010; 107:13426-13431. [PubMed: 20616080]

42. Jeon K, Lim H, Kim JH, et al. Differentiation and transplantation of functional pancreatic beta cells generated from induced pluripotent stem cells derived from a type 1 diabetes mouse model. Stem Cells Dev. 2012; 21:2642-2655. [PubMed: 22512788]

43. Chen YF, Tseng CY, Wang HW, et al. Rapid generation of mature hepatocyte-like cells from human induced pluripotent stem cells by an efficient three-step protocol. Hepatology. 2012; 55:1193-1203. [PubMed: 22095466] 
44. Yu Y, Liu H, Ikeda Y, et al. Hepatocyte-like cells differentiated from human induced pluripotent stem cells: relevance to cellular therapies. Stem Cell Res. 2012; 9:196-207. [PubMed: 22885101]

45. Grobstein C. Inductive epithelio-mesenchymal interaction in cultured organ rudiments of the mouse. Science. 1953; 118:52-55. [PubMed: 13076182]

46. Platt JL, Brown DM, Granlund K, et al. Proteoglycan metabolism associated with mouse metanephric development: morphologic and biochemical effects of $\beta$-d-xyloside. Dev Biol. 1987; 123:293-306. [PubMed: 3653508]

47. Platt JL, Trescony P, Lindman BJ, Oegema TR. Heparin and heparan sulfate delimit nephron formation in fetal metanephric kidneys. Dev Biol. 1990; 139:338-348. [PubMed: 2140104]

48. Badylak SF, Taylor D, Uygun K. Whole-organ tissue engineering: decellularization and recellularization of three-dimensional matrix scaffolds. Annu Rev Biomed Eng. 2011; 13:27-53. [PubMed: 21417722]

49. Badylak SF, Weiss DJ, Caplan A, Macchiarini P. Engineered whole organs and complex tissues. Lancet. 2012; 379:943-952. [PubMed: 22405797] This study from a leading authority in tissue engineering reviews the current state of knowledge and questions, yet unanswered in the use of artificial matrices and de-cellularized organs for the generation of organ replacements.

50. Sgroi A, Serre-Beinier V, Morel P, Buhler L. What clinical alternatives to whole liver transplantation? Current status of artificial devices and hepatocyte transplantation. Transplantation. 2009; 87:457-466. [PubMed: 19307780]

51. Zhao LF, Pan XP, Li LJ. Key challenges to the development of extracorporeal bioartificial liver support systems. Hepatobiliary Pancreat Dis Int. 2012; 11:243-249. [PubMed: 22672816]

52. Wertheim JA, Baptista PM, Soto-Gutierrez A. Cellular therapy and bioartificial approaches to liver replacement. Curr Opin Organ Transplant. 2012; 17:235-240. [PubMed: 22476224]

53. Yu Y, Fisher JE, Lillegard JB, et al. Cell therapies for liver diseases. Liver Transpl. 2012; 18:9-21. [PubMed: 22140063]

54. Ott HC, Matthiesen TS, Goh SK, et al. Perfusion-decellularized matrix: using nature's platform to engineer a bioartificial heart. Nat Med. 2008; 14:213-221. [PubMed: 18193059]

55. Hammerman MR. Transplantation of embryonic organs. Am J Transplant. 2004; 4(Suppl. 6):1424. [PubMed: 14871270]

56. Yokoo T, Fukui A, Matsumoto K, Okabe M. Stem cells and kidney organogenesis. Front Biosci. 2008; 13:2814-2832. [PubMed: 17981756]

57. Ogle BM, Knudsen BE, Nishitai R, et al. Toward the development of human T cells in swine for potential use in adoptive T cell immunotherapy. Tissue Eng. 2009; 15:1031-1040.

58. Ogle BM, Butters KB, Plummer TB, et al. Spontaneous fusion of cells between species yields transdifferentiation and retroviral in vivo. FASEB J. 2004; 18:548-550. [PubMed: 14715691] 


\section{KEY POINTS}

- $\quad$ The demand for organ transplantation is likely to increase in the next decades despite the advances in medicine and technology; this consideration will play an important role in weighing how technologies other than transplantation can be developed and applied.

- Among the various approaches to replacing organs, the use of pluripotent stem cells, especially those generated from the individual needing treatment, has the appeal because in principle the cells have the ability to form any organ and are histocompatible with the individual needing treatment.

- One key challenge to using stem cells for organ replacement is determining how to coax the cells to form a structure of sufficient size and function to serve the individual needing treatment.

- A challenge potentially eclipsing the technology will be determining whether and how society will meet the cost of applying new approaches to organ replacement. 


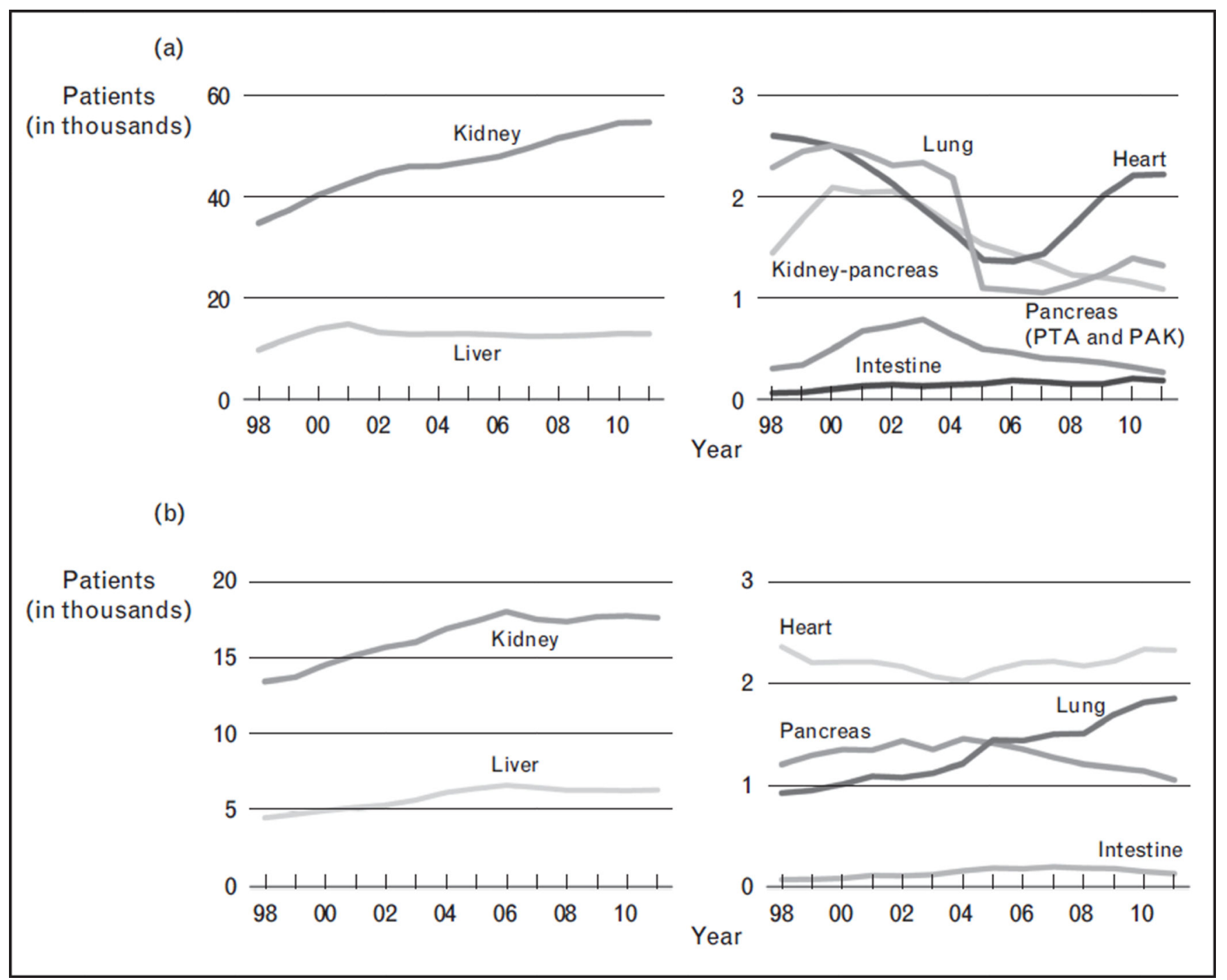

FIGURE 1.

The demand for organ transplants and the supply of organs for transplantation. Demand for organ transplants is defined as the number of individuals on waiting lists (those on multiple waiting lists are counted once) in the USA. The supply of organs is defined as the number of transplants performed in the USA. Reproduced with permission from the Annual Report of the Organ Procurement and Transplantation Network and the Scientific Registry of Transplant Recipients [6--]. 

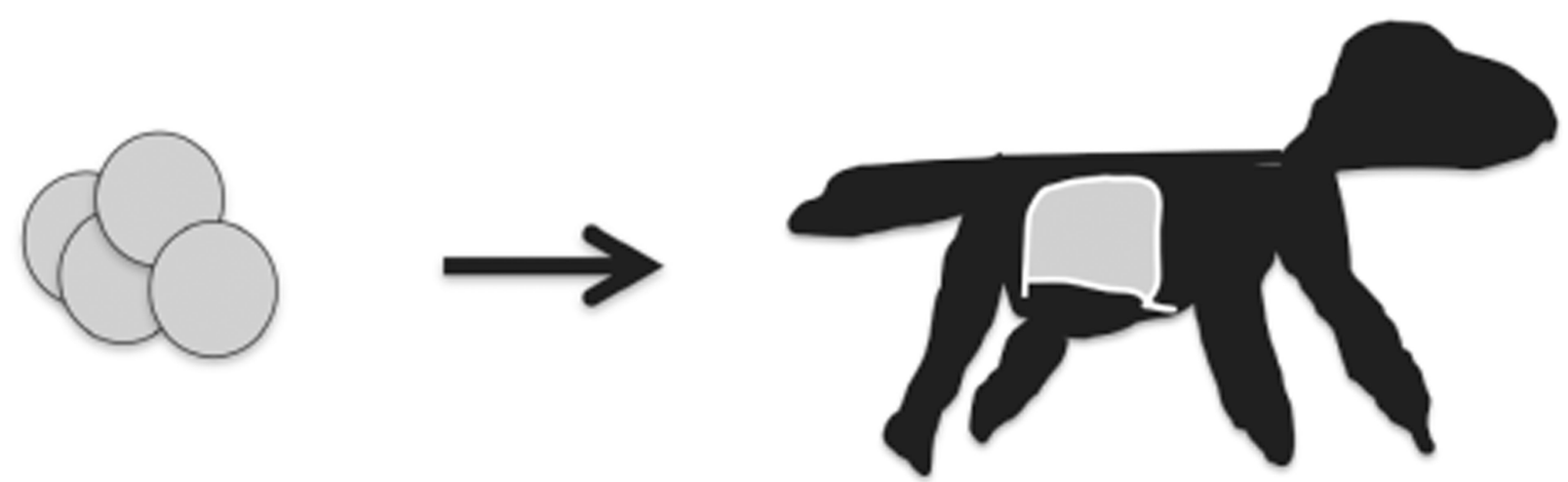

Stem cells

\section{Fetus}
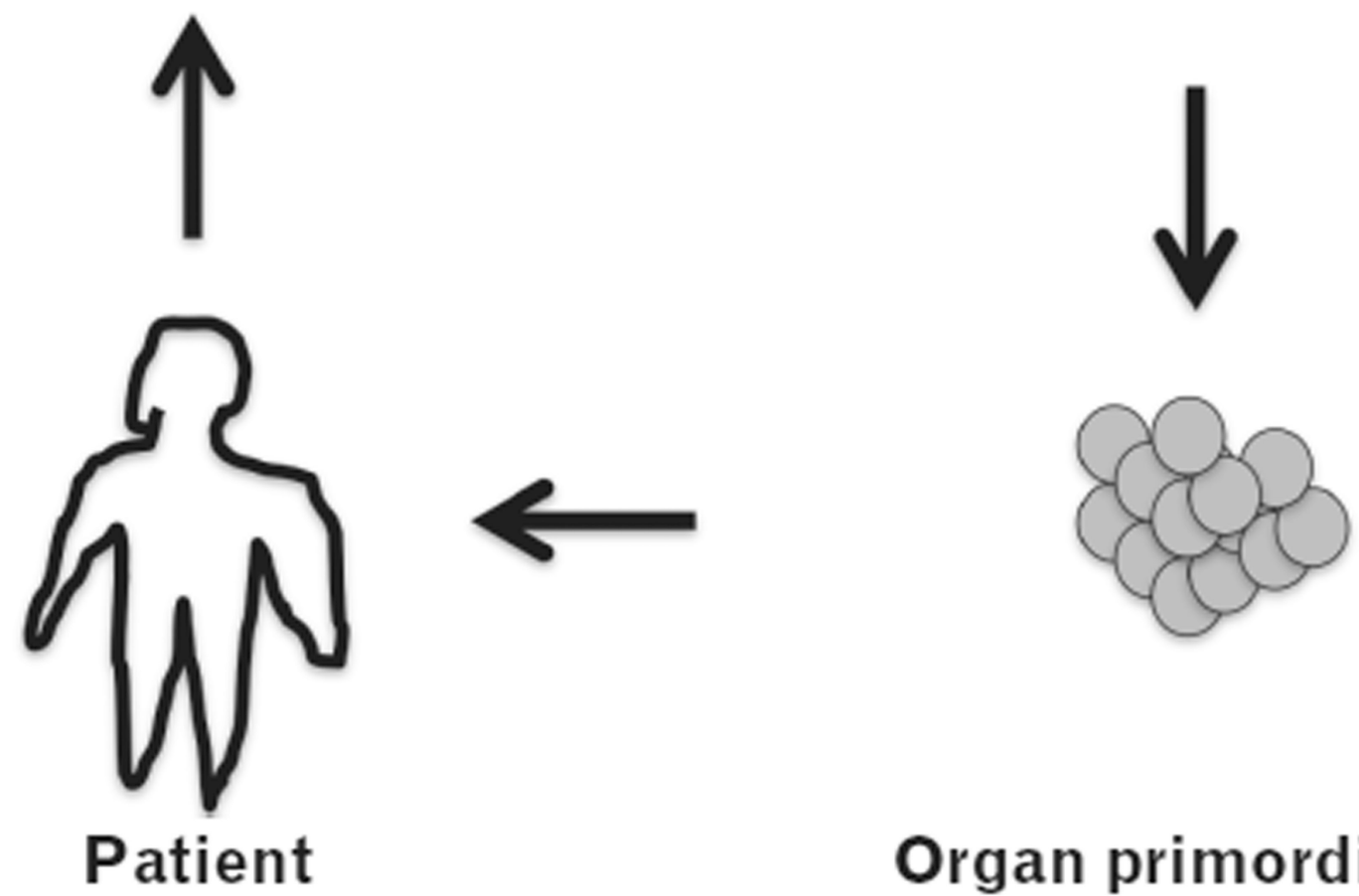

Organ primordium

FIGURE 2.

Combining technologies for organ replacement. The figure illustrates a strategy proposed previously by the authors $[1,4,18]$. The patient needing organ replacement is used either as a source of pluripotent stem cells or of mature cells that are made pluripotent by the nuclear transfer or other manipulation to generate induced pluripotent stem cells. The stem cells are transferred to a developing fetus, where the microenvironment coaxes the cells to become the primordium of the needed organ or a mature organ. The primordium or mature organ is harvested and transplanted into the human patient. Use of the primordium is preferred because it would acquire a vascular supply from the patient rather than from the animal; however, use of primordial might not be feasible for lung and perhaps for heart [18]. 


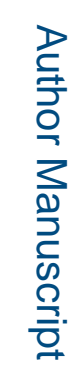

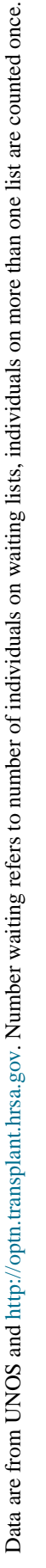

Curr Opin Organ Transplant. Author manuscript; available in PMC 2016 June 16. 


\section{Table 2}

Some technologies used for organ replacement

\begin{tabular}{lllll}
\hline Technology & Supply & Feasibility now & Hurdles & Cost \\
\hline Allotransplant & Limited & Yes & Supply and immunity & Moderate \\
\hline ES cells & Unlimited & No & OF and immunity & Moderate or high \\
\hline Cloning & Unlimited & No & OF and ? immunity & High \\
\hline iPS cells & Unlimited & No & OF & High \\
\hline Organogenesis & $?$ & No & Size, maturation, and function & High \\
\hline In-vivo organogenesis & $?$ & No & Maturation and function & ? Moderate \\
\hline Devices & Unlimited & Yes for heart & Toxicity and endurance & High \\
\hline Xenotransplantation & Unlimited & Yes & Immunity & Low \\
\hline
\end{tabular}

Cloning, cloning by nuclear transfer; ES cells, embryonic stem cells; iPS cells, induced pluripotent stem cells; OF, organ formation. 